\title{
The Effect of Cash Holding, Firm Size, and Financial Leverage to Earning Management in State-Owned Enterprises (SOEs)
}

\author{
Muhammad Elmas Fadlli \\ Telkom University \\ Khairunnisa \\ Telkom University
}

\begin{abstract}
This research was conducted to determine the simultaneous and partial influence between cash holding, firm size, and financial leverage on earnings management in SOEs Companies listed on the Indonesia Stock Exchange during 2012-2018. The method in this study used a quantitative method. This research uses descriptive research with case study research type. The sampling technique in this study used a purposive sampling technique by obtaining 12 sample companies with a period of 7 years to obtain 84 sample units. This research used a logistic regression analysis method using SPSS 25.0 software. The results of this study indicate that cash holding variables, firm size, and financial leverage simultaneously have a significant effect on earnings management. While partially, cash holding variables, firm size, and financial leverage do not affect earnings management.
\end{abstract}

Keywords: Earning Management; Cash Holding; Firm Size; Financial Leverage.

\section{Introduction}

The role of the Indonesian Stock Exchange in helping the economy in Indonesia is enormous. Not only limited to private companies, but State-Owned Enterprises (SOEs) also participate in the capital market to increase efficiency and effectiveness and help cover the state budget deficit. It can be identified from the growth in the number of SOEs entities listed on the IDX that continues to increase every year. State-Owned Enterprises (SOEs) that are listed on the IDX are mostly SOE that is related to the leading sectors in the Indonesian economy and are large-scale SOE, have the potential to become global players and have good ability to generate profits. The Indonesia Stock Exchange (IDX) listed the number of officially registered SOE as of September 2019 of 20 issuers consisting of various sectors, namely pharmaceuticals, banks, energy, construction, mining, metals, cement, transportation, and telecommunications. However, the condition of BUMN in Indonesia is quite alarming because it does not follow the rules set out in PSAK, such as manipulating financial statements by carrying out earnings management actions.
One case in Indonesia that practices earnings management is PT. Garuda Indonesia (GIAA). In the 2018 yearbook report, GIAA is suspected of carrying out earnings management practices. PT Garuda is indicated to do "Window Dressing," in which Garuda has carried out engineering practices using accounting tricks to make the company's balance sheet and income statement look better than it is. Garuda managed to record a profit of up to $\$ 809.85$ thousand US (Rp. 11.54 billion), far better than the balance sheet in 2017, which lost up to \$216.58 million. The two Garuda Indonesia commissioners, Chairal Tanjung and Dony Oskaria, refused to sign the Garuda 2018 annual book report. They did not agree with any of the cooperation transactions with PT Mahata Aero Teknologi. Of the contract value of US \$ 239.94 million for 15 years, PT Mahata has only paid the US $\$ 6.8$ million, and the remainder should be recorded as receivables. However, Garuda's management still writes it as income. Chairal, as the board of commissioners, stated, "Mahata contract transaction records with Garuda should not be recognized as revenue in the fiscal year 2018. The recording is contrary to the Financial 
Accounting Standards Guideline (PSAK) No. 23 of 2010 concerning income " (beritagar.id, 30 April 2019).

The phenomenon related to earnings management also occurs in PT Timah (TINS). PT Timah (Persero) Tbk is suspected of providing fictitious financial statements in the first semester of 2015 ago. This fictitious financial statement activity was carried out to cover up PT Timah's financial performance, which continued to be worrying. The Chairman of the Timah Employees Association, Ali Samsuri, revealed that PT Timah's financial condition has been unhealthy for the past three years. "Timah Employee Association assessed that directors had done a lot of public lies through the media, namely in the press release of the first half of 2015 financial statements which said that the efficiency and strategy had led to positive performance. In fact, in the first half of 2015, operating profit loss of Rp59 billion, "Ali said in his speech in front of the BUMN Ministry Building. Therefore, the Timah Employee Association demands that the board of directors immediately resign. According to Ali, the time given for almost two years by the Timah Employee Association was not successfully utilized by the board of directors to fix the company's performance. However, if the company does not fulfill this guidance, Timah Employee Association threatens to suspend operations temporarily until there is clarity from the board of directors. (economy.okezone.com, January 27, 2016).

One of the impacts of the earnings management action is that it can cause the company to experience a substantial loss to make the company go bankrupt. The survival of a company depends on the financial statements prepared by management, to convey information about the company's actual economic condition to internal and external parties of the company without any manipulation of financial statements (Kasmir, 2014:7). However, the information submitted by management is often not following actual conditions or what is called asymmetric information. In addition to the information asymmetry between management and shareholders, management also tends to take actions that are not appropriate (dysfunctional behavior) (Susanti, Surya, \& Azhari, 2016). It can lead to a conflict between the interests of two parties, namely agents and principals, or what is called an agency conflict. Agency conflict will arise if each party, both principal and agent, has different interests and wants to fight for their respective interests (Revinsia, Rahayu, \& Lestari, 2019). With the differences in interests, managers use it to achieve benefits by conducting Dysfunctional Behavior, one of which is to perform earnings management actions.

Earnings management is divided into three types; namely, managers increase earnings in the current period, managers do "big bath" through reducing earnings in a period, managers reduce earnings fluctuations with income smoothing (Subramanyam \& Wild, 2013:108). The type of earnings management used in this study is income smoothing. The reason researchers chose the practice of income smoothing because the practice of manipulation of financial statements most often done by management today is the practice of income smoothing. Whereas earnings management, in the form of increasing income (increasing income) or decreasing profit (big bath), is included as part of income smoothing practices. Income smoothing is done by increasing or decreasing the profit to be reported by moving income from a more successful year to a less profitable year. Besides, the practice of income smoothing is challenging to measure the level of fraud because the rate of change in the company's profit does not experience significant changes or is still considered in a stable condition (Subramanyam \& Wild, 2013:108).

Income smoothing has become a topic of many previous studies. Based on research conducted by (Pratama, Helliana, \& Sofianty, 2018), (Ayunika \& Yadnyana, 2018), (Putri \& Budiasih, 2018), (Handoyo \& Fathurrizki, 2018), (Natalie \& Astika, 2016), (Fiscal \& Steviany, 2015), (Mambraku \& Hadiprajitno, 2014), (Parijan, 2013), and (Mohammadi, Maharlouie, \& Mansouri, 2012) state that there are variables that are thought to influence earnings management actions and show inconsistent results between researchers one with the other researchers is cash holding, firm size, and financial leverage. 
Based on the phenomena of PT Garuda Indonesia (GAA) and PT Timah (TINS), the company's cash holding level increases every year. The increase in the company's cash holding amount is allegedly not only used to finance the company's operational activities but is also used to cover company losses so that it looks stable in front of investors. Likewise, the level of firm size GAA and TINS has increased every year, in other words, the larger the size of the company, the better the reputation of the company in generating profits. In order to maintain the company's reputation, management will do all the ways, one of which is earnings management. Besides, the leverage levels of GAA and TINS companies also increase every year. The higher the debt the company has, it shows that the company has a high level of risk that the company will not be able to repay the debt. Therefore, it can be assumed that to cover the high level of risk, and the management will take earnings management actions so that the company will still look good in front of investors.

Based on this phenomenon and its relationship with the variables that influence earnings management, the authors are interested in conducting further research on these variables. It makes the author's background to choose the title "The Effect of Cash Holding, Firm Size, and Financial Leverage to Earning Management in StateOwned Enterprise (SOE) Companies Listed on BEI during 2012-2018”.

\section{Literature Review and Hypothesis Development}

\section{Agency Theory}

According to (Handayani, 2016), agency theory is a relationship that involves a contract between members in a company that is the principal (shareholders or investors) and agents (management). In agency theory (Jensen \& Meckling, 1976) also explained that the interests between shareholders or investors and management are not always in line with what has been previously determined. The difference in interests between shareholders and management can cause many problems in the company. Therefore, to avoid this, it is necessary to provide incentives to management that are believed to minimize the occurrence of irregularities. Besides, monitoring costs are also needed to oversee management so that they do not act arbitrarily. The provision of incentives and monitoring costs incurred can be referred to as agency costs. As a guarantee of the management not to carry out such deviant activities, the management will provide bonding costs. These costs are incurred by management to convince shareholders not to worry about their performance. Based on the explanation of the agency theory, some problems can arise in the company that makes the condition of the company worse, including information asymmetry and differences in interests between the principal and agent. So, in this case, it will create opportunities for company management to take earnings management actions.

\section{Earning Management}

The type of earnings management used in this study is income smoothing. Income smoothing is an action that management does to achieve a certain desired level of profit by increasing or decreasing earnings to be reported by moving more profitable year income to less favorable years (Trisnawati, Nazar, \& Yudowati, 2017). The income smoothing action was tested by the Eckel index (1981). Eckel uses the Coefficient Variation (CV) income variable and the net sales variable. According to Eckel (1981) (Butar \& Sudarsi, 2012), which states that the dependent variable in this study is a qualitative index and is also called a dummy variable. After $\mathrm{CV} \Delta \mathrm{I}$ and $\mathrm{CV} \Delta \mathrm{S}$ are known, each company is given a status. If $\mathrm{CV} \Delta \mathrm{I}<\mathrm{CV} \Delta \mathrm{S}$, then the company is classified as a company that does income smoothing (given a value of 1). If $\mathrm{CV} \Delta \mathrm{I}>\mathrm{CV} \Delta \mathrm{S}$, then the company is classified as a company that does not do income smoothing (given a value of 0 ).

\section{Cash Holding}

Cash holding is an asset that is used by managers as a tool to carry out highly liquid business activities and protect companies from cash shortfalls (Putri \& Budiasih, 2018). The existence of cash in the company, the manager's performance can be seen from the actions taken by managers to keep the increase in cash in the company remains stable. Managers use cash holding to minimize external funding and company operations. In this study, cash holding 
by comparing the amount of cash and cash equivalents held by the company with the total assets of the company. Previous researchers have previously studied cash holding, but there are differences between researchers with other researchers. Based on research conducted by (Pratama, Helliana, \& Sofianty, 2018), (Natalie \& Astika, 2016), (Mambraku \& Hadiprajitno, 2014), and (Mohammadi, Maharlouie, \& Mansouri, 2012) which stated that cash holding influences significant positive effect on income smoothing. However, the results of the study are different from the results of research conducted by (Eni \& Suaryana, 2018) and (Putri \& Budiasih, 2018), which states that cash holding does not affect income smoothing.

\section{Firm Size}

The Firm size is only divided into three categories, namely large companies, mediumsized companies, and small firms (Hastria, Rasuli, \& Nurazlina, 2014). Firm size is one indicator to measure the size of a company, which can be identified from the total assets owned by the company (Fiscal \& Steviany, 2015). In other words, the higher the assets owned by the company, it can be interpreted that the company has a large company size. In this study, firm size is proxied by calculating the natural logarithm value multiplied by the total value of the company's assets. Previous researchers have previously studied the firm size, but there are differences between researchers with other researchers. Based on research conducted by (Ayunika \& Yadnyana, 2018) (Fiscal \& Steviany, 2015), and (Parijan, 2013) which states that firm size has a significant positive effect on income smoothing. However, the results of these studies differ from the results of research conducted by (Eni \& Suaryana, 2018), (Ginantra \& Putra, 2015), (Sherlita \& Kurniawan, 2013), and (Handoyo \& Fathurrizki, 2018) which states that firm size does not affect income smoothing.

\section{Financial Leverage}

Financial leverage is one of the financial ratios used to measure how much the company's assets have been financed by the use of debt or how much the company's debt affects the management of assets (Fahmi, 2014:127). A company that has a high level of debt can pose a considerable financial risk because it may impact that the company will not be able to cover its debt with the assets it has. In this study, financial leverage is proxied by Debt to Asset Ratio (DAR), which is by comparing the total debt held by the company with the total assets owned. Previous researchers have previously studied financial leverage, but there are differences between researchers with other researchers. Based on research conducted by Putri \& Budiasih (2018), Ayunika \& Yadnyana (2018), Fiscal \& Steviany (2015), and (Handoyo \& Fathurrizki, 2018) which states that financial leverage has a significant positive effect on income smoothing. However, the results of these studies are different from the results of research conducted by (Ginantra \& Putra, 2015), (Natalie \& Astika, 2016), (Sherlita \& Kurniawan, 2013), and (Parijan, 2013) which states that financial leverage does not affect leveling profit.

\section{Cash Holding and Earning Management}

Cash holding is an asset that is used by managers as a tool to carry out business activities that are highly liquid and protect companies from cash shortfalls (Putri \& Budiasih, 2018). The very liquid nature of cash holding makes cash very easy to be disbursed and easy to transfer, so it makes cash easily hidden or used for illegal actions. The existence of cash in the company allows investors to assess the performance of managers from their ability to keep the increase in cash in the company remains stable. One of the actions taken to keep cash is stable by making income smoothing. Based on the description above, it can be assumed that the higher the cash holding owned by the company, the higher the income smoothing by the company. It is in line with research conducted by (Pratama, Helliana, \& Sofianty, 2018), (Natalie \& Astika, 2016), (Mambraku \& Hadiprajitno, 2014), and (Mohammadi, Maharlouie, \& Mansouri, 2012) which stated that cash holding influences significant positive effect on income smoothing.

Hypothesis 1: Cash Holding partially has a significant positive effect on income smoothing 


\section{Firm Size and Earning Management}

Firm size is one indicator to measure the size of a company, which can be identified from the total assets owned (Fiscal \& Steviany, 2015). The higher the total assets owned by a company shows that a company has good prospects in a relatively long period and illustrates that a company is more capable and more stable in generating profits (Kurniasih \& Sari, 2013). Therefore, large companies will avoid profits that tend to fluctuate dramatically, thereby encouraging companies to practice income smoothing. Based on the description above, it can be assumed that the higher the company does the total assets owned by the company or the higher the size of the company, the income smoothing will also be higher. It is in line with research conducted by Ayunika \& Yadnyana (2018), Fiscal \& Steviany ( 2015), and Parijan (2013), which stated that firm size influences significant positive effects on income smoothing.

Hypothesis 2: Firm size partially has a significant positive effect on income smoothing

\section{Financial Leverage and Earning Management}

Financial Leverage is one of the financial ratios used to measure how much the company's assets have been financed by the use of debt or how much the company's debt affects the management of assets (Fahmi, 2014:127). The high level of leverage indicates that the use of debt to fund assets is also getting bigger and causes the company to have a high risk because the company is feared to be unable to cover its debts with its assets (Ulya \& Khairunnisa, 2015). Therefore, to cover the high level of risk, the company will tend to practice income smoothing so that the company remains stable in front of investors. Based on the description above, it can be assumed that the higher the level of leverage owned by the company, the smoothing of profits made by the company will also be higher. It is in line with research conducted by Putri \& Budiasih (2018), Ayunika \& Yadnyana( 2018), Fiscal \& Steviany (2015), and (Handoyo \& Fathurrizki, 2018) which stated that financial leverage influences significant positive effect on income smoothing.

Hypothesis 3: Financial leverage partially has a significant positive effect on income smoothing

\section{Methods}

\section{Sampling}

The population used in this research is SOEs Companies Listed on the Indonesia Stock Exchange for the 2012-2018 period. The sampling techniques used are non-probability sampling or purposive sampling with sample determination criteria as in the table below:

Table 1. Purposive Sampling

\begin{tabular}{llc}
\hline No & Sample Criteria & Number \\
\hline 1. & SOEs companies listed on the Indonesia Stock Exchange in 2012-2018 & 20 \\
2. & SOEs companies that do not have a positive profit in 2012-2018 & $(4)$ \\
3. & SOEs banking companies listed on the Indonesia Stock Exchange in 2012-2018. & $(4)$ \\
\hline \multicolumn{2}{l}{ The number of samples used as research objects } & 12 \\
\hline Amount of samples in research (7 years) & 84 \\
\hline
\end{tabular}

Source: Data that has been processed (2019)

\section{Measure}

The type of research used in this study is quantitative research. The following is the calculation of accounting variables consisting of Cash Holding, Firm Size, and Financial Leverage used, as well as the calculation of non-accounting variables consisting of Income Smoothing. 
Table 2. Operationalization Variabel

\begin{tabular}{|c|c|c|}
\hline Variable & Operationalization & Scale \\
\hline Cash Holding & Cash Holding $=\frac{\text { Cash }+ \text { Cash Equivalents }}{\text { Total Assets }}$ & Ratio \\
\hline Firm Size & Firm Size $=$ Ln Total Assets & Ratio \\
\hline Financial Leverage (DAR) & Debt to Asset Ratio $=\frac{\text { Total Debt }}{\text { Total Assets }} \times 100 \%$ & Ratio \\
\hline Income Smoothing & $\begin{array}{l}\text { The income smoothing action was tested by the Eckel index } \\
\text { (1981). Eckel uses the Coefficient Variation (CV) income } \\
\text { variable and the net sales variable. After } \mathrm{CV} \Delta \mathrm{I} \text { and } \mathrm{CV} \Delta \mathrm{S} \text { are } \\
\text { known, each company was given a status (dummy variable): } \\
\text { 1. If } \mathrm{CV} \Delta \mathrm{I}<\mathrm{CV} \Delta \mathrm{S} \text {, then the company is classified as a } \\
\text { company that does income smoothing (given a value of } \\
\text { 1). } \\
\text { 2. If } \mathrm{CV} \Delta \mathrm{I}>\mathrm{CV} \Delta \mathrm{S} \text {, then the company is classified as a } \\
\text { company that does not do income smoothing (given a } \\
\text { value of } 0 \text { ). }\end{array}$ & Nominal \\
\hline
\end{tabular}

Source: Data that has been processed (2019)

The logistic regression analysis model used in this study is as follows:

$$
\begin{aligned}
\operatorname{Ln} \frac{1}{1-I S}=\propto & +\beta_{1} C H+\beta_{2} U P+\beta_{3} F L \\
& +\varepsilon
\end{aligned}
$$

\section{Results}

\section{Descriptive statistics}

Descriptive statistical analysis was performed using 84 data from SOE companies. The outcome descriptive statistics are presented in Table 3.

Table 3. Descriptive Analysis

\begin{tabular}{llllll}
\hline & $\mathbf{N}$ & Minimum & Maximum & Mean & Std. Deviation \\
\hline Income & 84 & 0 & 1 & 0.55 & 0.501 \\
Smoothing & & & & & \\
Cash Holding & 84 & 0.03553 & 0.70136 & 0.17449 & 0.11866 \\
Firm Size & 84 & 27.81216 & 32.95985 & 30.69724 & 1.19689 \\
Financial & 84 & 0.08379 & 0.84999 & 0.52870 & 0.19956 \\
\hline
\end{tabular}

Leverage

Valid N (listwise) $\quad 84$

Source: Output SPSS 25.0

Based on data from Table 3 above, it shows each of the minimum values, maximum value, average (mean), and standard deviation with the total amount of 84 data. It is known that the dependent variable of this study is income smoothing, which has a minimum value of 0 and a maximum value of 1 . The mean value is 0.55 , as well as the standard deviation of 0.501 . It shows a higher mean value than standard deviation which means that the data in this study does not vary or group data (homogeneous). If the data tested is homogeneous, this indicates a pretty good result because the standard deviation is a deviation of each data item against the expected value.

The Cash Holding variable has a minimum value of 0.03553 and a maximum value of 0.70136 . The mean value of 0.17449 , as well as the standard deviation of 0.11866 . It indicates that the mean value is greater than the standard deviation, which means that the data in this study does not vary or group data (homogeneous). If the data tested is homogeneous, this indicates a pretty good result because the standard deviation is a 
deviation of each data item against the expected value.

The Firm Size variable has a minimum value of 27.81216 and a maximum value of 32.95985 . The mean value of 30.69724 , as well as the standard deviation of 1.19689. It indicates that the mean value is greater than the standard deviation, which means that the data in this study does not vary or group data (homogeneous). If the data tested is homogeneous, this indicates a pretty good result because the standard deviation is a deviation of each data item against the expected value.

The Financial Leverage variable has a minimum value of 0.08379 and a maximum value of 0.84999 . The mean value of 0.52870 , as well as the standard deviation of 0.19956 . It indicates that the mean value is greater than the standard deviation, which means that the data in this study does not vary or group data (homogeneous). If the data tested is homogeneous, this indicates a pretty good result because the standard deviation is a deviation of each data item against the expected value.

\section{Logistic Regression Test}

The outcomes of the logistic regression test are comprehensively presented in Table 4, Table 5, Table 6, Table 7 and Table 8

Table 4. Hosmer and Lemeshow's Goodness of Fit Test

\begin{tabular}{llll}
\hline Step & Chi-square & df & Sig. \\
\hline 1 & 7.622 & 8 & .471 \\
\hline
\end{tabular}

Source: Output SPSS 25.0

In table 4, the Chi-Square value or the statistical value of Hosmer and Lemeshow's is 7,622 , with a significant probability of 0.471 . The significance probability value is higher than 0.05 , then hypothesis 0 can be accepted, and the regression model used is fit with the data. It illustrates that the regression model used can predict the value of observation.

Table 5. Overall Model Fit

Overall model fit (-2LogL)

\begin{tabular}{ll}
\hline -2LogL Block Number 0 & Has value 115.686 \\
-2LogL Block Number 1 & Has value 106.955
\end{tabular}

Source: Data that has been processed (2019)

In table 5 , the initial $-2 \log \mathrm{L}$ value (Block Number 0) has a value of 115,686, and the final $-2 \log L$ value (Block Number 1) has a value of 106,955. Based on these results, it can be identified that there is a decrease in the value of $-2 \log L$ of 8,731 . Then, with the decrease of the final $-2 \log L$ value from the initial $-2 \log L$ value, it can be concluded that the $\mathrm{Ha}$ hypothesis is accepted, which illustrates the regression model used in the study, which is getting better or fit with the data.

Table 6. Model Summary

\begin{tabular}{llll}
\hline Step & -2 Log likelihood & Cox \& Snell R Square & Nagelkerke R Square \\
\hline 1 & $106.955^{\mathrm{a}}$ & .099 & .132 \\
\hline
\end{tabular}

Source: Output SPSS 25.00

In table 6, the obtained value of Cox \& Snell R Square is 0.101, and Nagellkerke's R Square value is 0.132 . So it can be concluded that the cash holding variable, firm size, and financial leverage can describe variations in earnings management practices in the form of income smoothing by $13.2 \%$, and the remaining $86.8 \%$ is illustrated by other factors not involved in this study. 
Table 7. Omnibus Test of Model Coefficients

\begin{tabular}{lllll}
\hline & & Chi-square & df & Sig. \\
\hline Step 1 & Step & 8.731 & 3 & .033 \\
& Block & 8.731 & 3 & .033 \\
& Model & 8.731 & 3 & .033 \\
\hline
\end{tabular}

Source: Output SPSS 25.00

In table 7, the Chi-Square value of 8,731 with a degree of freedom (df) of 3 , and a significance level or $p$-value of 0.033 . Thus, it can be concluded that $\mathrm{HO}$ (1) is rejected and $\mathrm{Ha}$ (1) is accepted because the value of 0.033 is smaller than 0.05 . It illustrates that the variable cash holding, firm size, and financial leverage together simultaneously influence the income smoothing of State-Owned Enterprise (SOE) listed on the Indonesia Stock Exchange in 2012-2018.

Table 8. Variables in Equation

\begin{tabular}{|c|c|c|c|c|c|c|c|}
\hline & & B & S.E. & Wald & df & Sig. & $\operatorname{Exp}(B)$ \\
\hline \multirow{4}{*}{ Step $1^{\mathrm{a}}$} & $\mathrm{CH}$ & -.003 & .003 & 1.225 & 1 & .268 & .997 \\
\hline & UP & -5179.700 & 3070.710 & 2.845 & 1 & .092 & .000 \\
\hline & FL & -.030 & .034 & .772 & 1 & .380 & .970 \\
\hline & Constant & 5.751 & 3.231 & 3.168 & 1 & .075 & 314.526 \\
\hline
\end{tabular}

Source: Output SPSS 25.00

Based on the information presented in table 8 , it can be explained that the significance value (sig.) of cash holding is 0.268 , which is higher when compared to the significant value of $5 \%(0.05)$. Then it can be determined that the hypothesis H0 (2) is accepted and Ha (2) is rejected. It shows that the cash holding variable has no significant effect on earnings management practices.

The significance value (sig.) of the firm size is 0.092 , which is higher when compared to the significant value of 5\% (0.05). Then it can be determined that the hypothesis $\mathrm{HO}$ (3) is accepted, and Ha (3) is rejected, and it shows that the firm size variable does not have a significant effect on earnings management practices.

The significance value (sig.) of financial leverage is 0.380 which is higher when compared to the significant value of 5\% (0.05). Then it can be determined that the hypothesis $\mathrm{HO}$ (4) is accepted and $\mathrm{Ha}(4)$ is rejected, and it shows that the financial leverage variable has no significant effect on earnings management practices.

Based on the results of the model analysis of logistic regression in the study, it resulted in an equation is: Earning
Management $=5.751-0.003$ Cash Holding 5179.700 Fim Size - 0.030 Financial Leverage $+\varepsilon$

\section{Discussion}

Based on Table 8 the analysis results showed that the value of the regression coefficient of Cash Holding of -0.003 with the significance level of $0.268>0.05(\alpha)$. It means that Cash Holding has no significant effect on Income Smoothing. Therefore, HO(2) is accepted and $\mathrm{Ha}(2)$ is rejected, which means that cash holding has no effect on earnings management practices in the form of income smoothing. The higher or lower cash holding does not affect the company to practice earnings management. Cash holding is measured by comparing the amount of cash and cash equivalents owned by the company with the total assets of the company. In the sample period it was found that several State-Owned Enterprises (SOEs) companies use cash holding only for functional activities, namely to finance operational activities, debt payments and dividend payments to shareholders, so managers cannot use cash holding for company interests such as carry out earnings management actions in the form of income smoothing. This research is in line with research conducted by Eni \& Suaryana (2018) and Putri \& Budiasih (2018), 
which states that cash holding does not affect income smoothing.

The value of the regression coefficient of Firm Size of -5179.7 with the significance level of $0.092>0.05(\alpha)$. It means that Firm Size has no significant effect on NIR. Therefore, H0.3 is accepted and $\mathrm{Ha}$ (3) is rejected, which means that firm size has no effect on earnings management practices in the form of income smoothing. The big or small size of the company does not influence the company to practice earnings management. In this study, firm size is proxied by calculating the natural logarithm value multiplied by the total value of the company's assets. In the sample period, it was found that several State-Owned Enterprises (SOEs) companies stated that maintaining the reputation or right name of the company is not to commit fraud, such as manipulation of financial statements (earnings management). Therefore earnings management actions in the form of income smoothing made by some companies are not triggered by the size of the company but can be triggered based on the goal of the company wanting more investment. This research is in line with research conducted by (Eni \& Suaryana, 2018), (Ginantra \& Putra, 2015), (Sherlita \& Kurniawan, 2013), and (Handoyo \& Fathurrizki, 2018) which states that firm size does not affect income smoothing.

The value of the regression coefficient of Financial Leverage of -0.030 with the significance level of $0.380>0.05(\alpha)$. It means that Financial Leverage has no significant effect on NIR. Therefore, HO(4) is accepted, and $\mathrm{Ha}(4)$ is rejected, which means that firm size has no effect on earnings management practices in the form of income smoothing. The big or small size of the company does not influence the company to practice earnings management. In this study, financial leverage is measured by comparing the amount of debt held by the company with the number of company assets. In the sample period, it was found that the level of debt owned by State-Owned Enterprises (SOEs) companies did not experience a significant increase, so the level of risk owned by the company was relatively small. With a small level of risk, making the company does not need to take earnings management actions in the form of income smoothing. Besides, management also believes that debt is not the reason for management to conduct income smoothing because the company can finance its operational costs by providing reserve funds and funding needs from other sources such as additional capital from investors. This research is in line with research conducted by (Ginantra \& Putra, 2015), (Natalie \& Astika, 2016), (Sherlita \& Kurniawan, 2013), and (Parijan, 2013) which states that financial leverage does not affect income smoothing.

\section{Conclusion}

Based on the analysis and discussion in the previous section, the conclusions are as follows; Simultaneously, variable cash holding, company size, and financial leverage affect earnings management. While partially, the cash holding variables, company size, and financial leverage do not affect earnings management.

Hopefully, this research can be used as material or a reference in the development of accounting, especially in the fields related to earnings management in the income smoothing field. It is hoped that future researchers will have broader implications for research on the same topic and can add, subtract, or replace research variables not analyzed in this study so that they can explain broader income management. In addition, it is hoped that further researchers can be added using a larger sample of companies, by adding sectors other than SOE companies that go public.

It is also expected that company management and investors can pay attention and look for other factors or other financial performance that can influence earnings management actions as a material for consideration in decision making because based on this research, the independent variables used are proven not to affect earnings management.

\section{References}

Afrianto, D. (2016, January 27). Timah Board of Directors Accused of Manipulation of Financial Statements [online]. economy.okezone.com.

Ayunika, N. P., \& Yadnyana, I. (2018). Influence of Firm Size, Profitability and Financial Leverage on Profit 
Flattening Practices in Manufacturing Companies. E-Journal of Udayana University Accounting. ISSN: 23028556, Vol. 25. doi:https://doi.org/10.24843/EJA.2018 .v25.i03.p29

Butar, L. K., \& Sudarsi, S. (2012). Effect of firm Size, Profitability, Leverage, and Institutional Ownership on Income Smoothing: An Empirical Study of Food and Beverages Companies Listed on the IDX. Dynamics of Accounting, Finance and Banking, November 2012, Vol. 1, No. 2. ISSN: 1979-4878, 143 158.

Cakti, A. (2019, May 30). The Minister Targets 2019 BUMN Profits Above Rp220 Trillion [online]. www.antaranews.com.

Eni, I. G., \& Suaryana, I. A. (2018). The Effect of Cash Holding, Profitability and Firm Size on Income Smoothing in Property Companies on the IDX. E-Journal of Udayana University Accounting. ISSN: 2302-8556, Vol. 23. doi:https://doi.org/10.24843/EJA.2018 .v23.i03.p03

Fahmi, I. (2014). Financial Statement Analysis. Bandung: Alfabeta.

Fiscal, Y., \& Steviany, A. (2015). The Effect of Firm Size, Profitability, Financial Leverage and Dividend Payout Ratio On Income Smoothing in The Manufacturing Companies Listed in Indonesia Stock Exchange Period 2010-2013. Accounting Journal \& Finance. ISSN: 2087-2054, Vol. 6, Halaman 11-24.

Ginantra, I. K., \& Putra, I. A. (2015). Effect of Profitability, Leverage, Firm Size, Public Ownership, Dividend Payout Ratio and Net Profit Margin on Income Smoothing. E-Journal of Udayana University Accounting. ISSN: $2302-$ 8556.

Handayani, S. (2016). Analysis of Factors Affecting Profit Flattening (Studies in the Mining Sector Industry and Pharmaceutical Industry Companies Listed on the IDX). Journal of
Economic and Accounting Research. Volume I No. 3, Oktober 2016. ISSN 2502 - 3764 .

Handoyo, S., \& Fathurrizki, S. (2018). Management Dysfunctional Behaviour toward Financial Statements: Income Smoothing Practice in Indonesia's Mining Industry Sector. Journal of Finance and Banking. ISSN: 24432687, Hal. 429-442. doi: http://jurnal.unmer.ac.id/index.php/jkd $\mathrm{p}$

Hastria, D., Rasuli, M., \& Nurazlina. (2014). Effect of Firm Size, Financial Leverage, Dividend Payout Ratio and Net Profit Margin on Income Smoothing Actions Performed by Automotive and Allied Product Companies Listing on the IDX. Vol. 1, No. 1. ISSN: 2355-6854.

Jensen, M. C., \& Meckling, W. H. (1976). Theory Of The Firm: Managerial Behavior, Agency Costs, And Ownership Structure. Journal of Financial Economics 3 (1976) 305360 .

Kasmir. (2014). Financial Statement Analysis. Jakarta: PT. Rajagrafindo Persada.

Kurniasih, T., \& Sari, M. M. (2013). Effects of Return On Assets, Leverage, Corporate Governance, Firm Size and Fiscal Loss Compensation on Tax Avoidance. Economic Study Bulletin, Volume 18, No. 1. ISSN 1410-4628, 58-66.

Mambraku, M. E., \& Hadiprajitno, P. B. (2014). The Effect of Cash Holding and Managerial Ownership Structure on Income Smoothing (Empirical Study of Manufacturing Companies Listed on the Indonesia Stock Exchange in 20102012). Diponegoro Journal of Accounting. ISSN (Online): $2337-$ 3806, Volume 3, Nomor 2, Hal. 1-9. doi:http://ejournal-

s1.undip.ac.id/index.php/accounting

Mohammadi, S., Maharlouie, M. M., \& Mansouri, O. (2012). The Effect Of Cash Holdings On Income Smoothing. Interdisciplinary Journal of 
Contemporary Research In Business, Vol. 4, No. 2. doi:ijcrb.webs.com

Natalie, N., \& Astika, I. P. (2016). Effects of Cash Holding, Bonus Plan, Auditor Reputation, Profitability and Leverage on Income Smoothing. E-Journal of Udayana University Accounting. ISSN: 2302-8556, Vol. 15.

Nirmala, R. (2019, April 30). The recording of the awkward Garuda Indonesia Profits [online]. beritagar.id.

Parijan, K. K. (2013). Income Smoothing Practices: An Empirical Investigation Of Listed Firms In Tehran Stock Exchange (TSE). Indian Streams Research Journal. ISSN No: 22307850, Vol. 3(Issue 5). doi:www.isrj.net

Pratama, R., Helliana, \& Sofianty, D. (2018). Effects of Cash Holding, Earning Per Share and Company Value on Income Smoothing. Proceedings of Accounting. ISSN: 2460-6561, Volume 4, No. 2.

Pratomo, M. N. (2019, March, 14). Judging by the great potential of BUMN to go public [online]. market.bisnis.com.

Putri, P. A., \& Budiasih, I. N. (2018). Effects of Financial Leverage, Cash Holding, and ROA on Income Smoothing on the Indonesia Stock Exchange. E-Journal of Udayana University Accounting. ISSN: $\quad 2302-8556, \quad$ Vol. 22. doi:https://doi.org/10.24843/EJA.2018 .v22.i03.p11

Revinsia, V. S., Rahayu, S., \& Lestari, T. U. (2019). The Effect of Cash Holding, Profitability, and Leverage on Income Smoothing (Case Study on Mining Sector Companies Listed on the Indonesia Stock Exchange in 2013-
2017). Edutech Consultant Bandung Journal of Public Literacy, Page 10-11.

Sekaran, U. (2014). Research Methods For Business. Jakarta: Salemba Empat.

Sherlita, E., \& Kurniawan, P. (2013). Analysis of Factors Affecting Income Smoothing Among Listed Companies in Indonesia. Journal of Technology (Social Sciences). eISSN 2180-3722. ISSN 0127-9696, Hal. 17-23.

Subramanyam, K., \& Wild, J. (2013). Financial Statement Analysis. Jakarta: Salemba Empat.

Sugianto, D. (2019, Agustus 12). 42 Years Established, Here's the Journey of the Indonesian Capital Market [online]. finance.detik.com.

Susanti, A., Surya, R. S., \& Azhari, S. (2016). Effect of Information Asymmetry, Firm Size, Managerial Ownership, and Capital Adequacy Ratio on Earnings Management. JOM Fekon, Vol. 3 No. 1 (February) 2016.

Trisnawati, M., Nazar, M. R., \& Yudowati, S. P. (2017). The Effect of Profitability, Dividend Payout Ratio and Financial Leverage on Profit Flattening Practices (Study of Companies listed in the 20112016 LQ45 Index). e-Proceeding of Management. Vol.4, No.3 December 2017, Page 2654.

Ulya, N., \& Khairunnisa. (2015). Effect of Firm Size, Profitability, Financial Leverage and Audit Quality on Profit Management Practices (Case Study on Manufacturing Companies Listed on the Indonesia Stock Exchange in 20112013). e-Proceeding of Management: Vol.2, No.1 April 2015. ISSN : 23559357, 324-331. 